Cristianismo pós-moderno: midrash do tempo messiânico segundo a teologia de Carlos Mendoza Álvarez *

\section{Cleusa Caldeira ${ }^{a}$}

Pontifícia Universidade Católica do Paraná, Brazil http:/ / orcid.org/0000-0001-7202-0682

RECEBIDO: 16-02-18. APROVADO: 13-06-18

Resumo: Partindo do pensamento de Carlos Mendoza Álvarez, descreve-se os traços constitutivos do cristianismo pós-moderno como um autêntico midrash da temporalidade messiânica. Pretendese responder a crucial pergunta: Como viver a esperança messiânica em meio à crescente espiral de violência que caracteriza os tempos pós-modernos? Trata-se de pensar a experiência cristá de Deus sob o signo irreversível da subjetividade autônoma e o fim da metafísica clássica, para pôr em relevo a pertinência e a significação do cristianismo no contexto da pós-modernidade. A questão da esperança enlaça-se à pergunta pelas "representaçóes do divino" e da "vida teologal" credíveis sob a cultura do fragmento.

Palavras-chave: Cristianismo pós-moderno; midrash; tempo messiânico; vida teologal; Carlos Mendoza Álvarez.
Postmodern Christianity: Midrash of Messianic Time According to the Theology of Carlos Mendoza Álvarez

Abstract: Based on the thought of Carlos Mendoza Álvarez, the constitutive traits of postmodern Christianity are described as an authentic midrash of messianic temporality. It is intended to answer the crucial question: How to live the messianic hope amid the growing spiral of violence that characterizes postmodern times? It is a question of thinking of God's Christian experience under the irreversible sign of autonomous subjectivity and the end of classical metaphysics to put in relief the relevance and significance of Christianity in the context of postmodernity. The question of hope is linked to the question about "representations of the divine" and "theological life," credible under the culture of the fragment.

Keywords: Postmodern Christianity; midrash; messianic time; theological life; Carlos Mendoza Álvarez.

\section{COMO CITAR:}

Caldeira, Cleusa. "Cristianismo posmoderno: midrash do tempo messiânico segundo a teologia de Carlos Mendoza Álvarez". Theologica Xaveriana 187 (2019): 1-25. https://doi.org/10.11144/javeriana. tx69-187.cpmtms

\title{
RECONHECIMENTO
}

Este artigo resulta da tese doutoral em teologia defendida na Faculdade de Filosofia e Teologia, FAJE, com início em 15 de março de 2013 e finalizaçáo em 31 de julho de 2017, sob o título: “Tempo messiânico e sacramentalidade da subjetividade vulnerável na obra de Carlos Mendoza Álvarez”. Sob o financiamento da Capes.

*Artigo de investigação

a Autor de correspondencia. Correio eletrônico: cleucaldeira@gmail.com 


\section{Introdução}

Depois de passar pela crítica desconstrucionista, na qual o cristianismo foi inserido em sua própria desconstrução, isto é, esvaziado de sua pretensão de totalidade e assumindo sua vocaçáo kenótica1, a teologia pode mostrar a pertinência da fides cristã no seio da racionalidade pós-moderna que assumiu a constitutiva vulnerabilidade da subjetividade exposta e aberta à transcendência ${ }^{2}$. Busca-se, pois, explicitar a atualidade e pertinência do cristianismo no contexto pós-cristão, pós-metafísico e pós-moderno a partir do pensamento do teólogo mexicano Carlos Mendoza Álvarez ${ }^{3}$. Partindo de um procedimento interdisciplinar, com a teoria do desejo mimético ${ }^{4}$, o pensamento desconstrucionista ${ }^{5}$, o pensamento antissistêmico ${ }^{6}$ e a teologia pragmática cremos não é possível compreender sua riqueza teológica sem uma aproximação à

${ }^{1}$ Caldeira, "Desconstrução do cristianismo: imperativo ontológico à experiência de Deus na pósmodernidade" (no prelo): para uma aproximação à proposta mendoziana da desconstrução do cristianismo.

${ }^{2}$ Ídem, “Teologia e niilismo pós-moderno: a subjetividade vulnerável como locus theologicus no pensamento de Carlos Mendoza Álvarez”, 810-838. A autora faz uma breve descriçáo da constituição da subjetividade pós-moderna como lugar teológico no pensamento de Carlos Mendoza.

${ }^{3}$ Nascido em Puebla em 24 de abril de 1961, México, frei dominicano, Carlos Mendoza Álvarez é considerado o maior expoente da teologia da libertaçáo em contexto pós-moderno. Autor de dezenas de livros e uma centena de artigos científicos e capítulos de livros, destacamos sua trilogia sobre a ideia de revelação no contexto da pós-modernidade: Deus liberans. La revelación cristiana en diálogo con la Modernidad. Los elementos fundacionales de la estética teológica (1996); El Dios escondido de la posmodernidad. Deseo, memoria e imaginación escatológica. Ensayo de teología fundamental posmoderna (2010); e Deus ineffabilis. Una teología posmoderna de la revelación del fin de los tempos (2015).

${ }^{4}$ Girar e Benoit, Rematar Clausewitz. Além da guerra. Diálogos com Benoit Chantre; Girard, Mentira romântica e verdade romanesca; ídem, Eu via satanás cair do céu como um raio. A teoria do desejo mimético foi desenvolvida pelo antropólogo René Girard e, posteriormente, assumida criativamente pela teologia por meio do teólogo James Alison.

${ }^{5}$ Nancy, La déclosion (Deconstrucción del cristianismo I); ídem, A adoração (Desconstrução do cristianismo, II). O pensamento desconstrucionista como principal característica da pós-modernidade radical nasce da desconstrução de Jacques Derrida, seguido por Gianne Vattimo, Jean-Luc Nancy e Jacques Marion.

${ }^{6}$ Robert y Rahnema, "La potencia de los pobres". Herdeiro do movimento zapatista mexicano, o movimento antisistêmico propóe uma política outra de caráter comunitário da palavra e da ação, parte das margens da história de dominação como indício histórico de mudança de mundo. Nesse sentido, da recepção criativa deste pensamento por nosso autor surge a expressão "desde baixo e desde o reverso" da história de dominação.

${ }^{7}$ Mendoza Álvarez, El Dios escondido de la posmodernidad. Deseo, memoria e imaginación escatológica. Ensayo de teología fundamental pós-moderna, 239-245. Em diálogo com a filosofia pragmática, Helmut Peuket descobriu o miolo pragmático da teologia capaz de explicar a instauraçáo da comunidade ilimitada do discurso. Se a pragmática do discurso constatou o "permanente triunfo dos verdugos", o teólogo alemão capturou o reverso dessa condição antropológica, visto que apesar do aparente triunfo dos verdugos, "sempre há justos que dão suas vidas pelos demais" (ibid.). 
fenomenologia ${ }^{8}$; visto que ela coloca em rota de conversão os nossos pressupostos metafísicos da experiência humano-divina, com a defesa da existência em permanente devir.

Diante da violência sistêmica que póe em risco o futuro da humanidade e do planeta, é inevitável perguntar: Como viver a esperança messiânica em meio à crescente "espiral de violência" que caracteriza os tempos pós-modernos? Uma pergunta que implica a possibilidade da experiência cristã de Deus depois do fim dos metarrelatos da Modernidade e da cristandade e, ainda, sob o signo irreversível da subjetividade autônoma e o fim da metafísica clássica. Nesse horizonte, Carlos Mendoza percorre um longo caminho filosófico-teológico a fim de postular, sob as novas condiçóes culturais, mediaçóes plausíveis à redençâo da humanidade no umbral do terceiro milênio.

Nesse sentido, a inculturação do Evangelho em tempos de fragmentos surge do desejo de "reconocer a chegada do fim dos tempos e a instauração do Reinado de Deus" capaz de suscitar a "(im)possível esperança" "11, a partir da imanência da história. Mais especificamente, "a partir de baixo e do reverso" da história de dominação. Uma “(im) possível esperança" significa que ela só é possível dentro da concepçáo do ser humano e de Deus kenóticos, tal como são tematizados pela racionalidade pós-moderna.

Em função dessa perspectiva kenótica, Carlos Mendoza tece a sua "teologia niilista da temporalidade messiânica" ${ }^{12}$, isto é, uma teologia da fraqueza do mistério de Deus que se revela na temporalidade messiânica. Denominamos tal tessitura como

${ }^{8}$ Mendoza Álvarez, "A recepção inacabada do Concílio Vaticano II no mundo latino-americano e caribenho. O caso da teologia da revelaçáa”, 265-287. Uma das grandes novidades no pensamento teológico de Carlos Mendoza reside exatamente na afirmação da impossibilidade da racionalidade teológica, em tempos pós-modernos, renunciar ao primado da subjetividade. Nesse marco epistemológico ele desenvolve uma reflexão teológica a partir da assunção da fenomenologia da subjetividade moderna e pós-moderna (ibid.). Em uma postura cordial diante de Descartes, Kant, Hegel, Heidegger, Emmanuel Levinas, Paul Ricoeur e os pós-modernos desconstrucionistas, Carlos Mendoza apresenta uma nova fase da teologia fundamental que transita entre fé e razáo no umbral da racionalidade pós-moderna marcada pelas globalizaçóes econômica, cultural e religiosa.

${ }^{9}$ Mendoza Álvarez, Deus ineffabilis. Una teología posmoderna de la revelación del fin de los tempos, 107. A expressáo "espiral de violência" [montée aux extrêmes] advém da leitura antropológica do real que realiza René Girard, que através da teoria do desejo mimético constata que o real é religioso e sacrificial; e por isso, violento (ibid.).

${ }^{10}$ Ibid., 256.

11 “(Im)possível esperança” é uma glosa nossa a “esperança possível” de Carlos Mendoza, para descrever a esperança credível em tempos pós-modernos, não como fuga do mundo ou espera de um resgate milagroso por parte de Deus; mas sua transfiguração a partir de dentro, sob a dinâmica da doação de si mesmo até o último suspiro.

${ }^{12}$ Mendoza Álvarez, Deus ineffabilis. Una teología posmoderna de la revelación del fin de los tempos. 
um midrash pós-moderno ${ }^{13}$, pois ele justifica a verdade plenamente revelada em Jesus de Nazaré no seio da racionalidade pós-moderna.

Sob a base de uma ontologia relacional da gratuidade ${ }^{14}$, Carlos Mendoza explicita a verdade do cristianismo conjugando a vida teologal com as potências da subjetividade vulnerável, ambas desconstruídas ${ }^{15}$. Se trata de focar na dimensão teologal da subjetividade exposta pela presença do outro. Assim, o teólogo mexicano reinterpreta a partir de um dinamismo antropológico-teologal a vita theologalis ${ }^{16}$, para descobrir os traços constitutivos da revelação. Esse dinamismo teologal designa a reconstituição da subjetividade em seu retorno fenomenológico ao evento originário, onde se acessa $\mathrm{o}$ "centro vazio", isto é, Deus em linguagem monoteísta, como a fonte e horizonte de toda subjetividade em doação ${ }^{17}$.

Em linguagem fenomenológica, chega-se ao momento de pensar no "despertar da subjetividade extrema”, isto é, na dimensão espiritual da subjetividade exposta e aberta à irrupção do outro ${ }^{18}$. Traça-se a gênesis do despertar da subjetividade que vive o desejo em doaçáo como imitaçáo de Cristo e na responsabilidade de habitar o mundo sob a “(im)potência potente" ${ }^{19}$. Com isso, descreve-se como a subjetividade iluminada

${ }^{13}$ De Santoyo, Experiência de Deus e catequese narrativa, 156-158. O significado do midrash como método hermenêutico deriva do verbo derásh, próprio da hermenêutica judaica. O significado original do verbo derásh consiste em "buscar", "procurar" algo que é da ordem do infinito. Por isso, mais do que um simples gênero literário, o midrash designa uma atitude de coraçáo de alguém que se debruça sobre a Escritura para encontrar uma palavra de Deus capaz de iluminar a existência concreta. Trata-se de uma atitude crente do reconhecimento de que a última palavra aos dilemas da existência vem de Deus encarnado. À luz da fé se torna possível acessar o "sentido querido por Deus" registrado nas Escrituras (ibid.). Diferente do derásh veterotestamentário, que busca encontrar uma nova palavra divina a partir de uma palavra do Livro, o neotestamentário parte da memória eclesial do evento Cristo como critério hermenêutico. Se para o dasharnim do judaísmo o texto bíblico é fonte da Palavra divina, no cristianismo a fonte é Cristo, sua mensagem e sua pessoa.

${ }^{14}$ Knauer, "Ontologia relacional", 19-41. A proposta de uma ontologia relacional indica uma ruptura epistemológica em relação à ontologia da substância, cuja característica fundamental é a substância e náo a relação.

${ }^{15}$ Mendoza Álvarez, El Dios escondido de la posmodernidad. Deseo, memoria e imaginación escatológica. Ensayo de teología fundamental posmoderna, 229. Seguindo a trilogia da fenomenologia, Carlos Mendoza assume o desejo, a memória e a imaginação como as potências de experiência da subjetividade vulnerável pós-moderna.

${ }^{16}$ Mendoza Álvarez, Deus ineffabilis. Una teología posmoderna de la revelación del fin de los tempos, 344.

${ }^{17}$ Caldeira, "Da Europa à América Latina. A vulnerabilidade como locus theologicus", 307-323.

${ }^{18}$ Mendoza Álvarez, El Dios escondido de la posmodernidad. Deseo, memoria e imaginación escatológica. Ensayo de teología fundamental pós-moderna, 346-347.

${ }^{19}$ Ibid., 278. "Impotência potente" é uma glossa nossa ao "poder do não-poder" que procede da gratuidade amorosa, cujo sentido denota o mimetismo depurado de sua rivalidade. Quando o Messias Jesus aparece como "vítima perdoadora" ele revela que o núcleo da subjetividade unida à temporalidade escatológico 
pelo resplendor da fé vivencia outra temporalidade que conduz para dentro da temporalidade messiânica no seio da violência intersubjetiva em sua dimensão planetária.

\section{Tempo messiânico e escatologia pós-moderna}

"El fin de los tiempos es ahora" ${ }^{20}$, afirma o teólogo mexicano. Mais do que denunciar a real possibilidade de uma iminente destruição total por conta dos excessos da razão técnico-científica, a chegada do "fim dos tempos" designa a implosão da temporalidade cronológica e o início de uma nova temporalidade. Partindo, pois, da mediação antropológica do sujeito potente em sua labilidade, trata-se de "repensar la historia más allá de su contradicción mimética violenta” ${ }^{21}$.

Como primeiro passo nesse procedimento deráshico, o teólogo mexicano faz uma epoché da ideia tradicional de escatologia ${ }^{22}$. Tal procedimento se faz necessário porque essa escatologia projeta a salvação para além da história e, consequentemente, conduz os crentes à inércia frente aos dramas do espaço público. Isso, entretanto, não significa negar a escatologia como promessa para toda a criação, mas de acentuar o seu caráter ético-político.

Com efeito, o modelo apologético de pensar o "fim dos tempos" esconde uma ideia de um Deus vingativo e mau, que destruirá o velho cosmo e instaurará outro eon. Essa ideia de escatologia típica da apologética tradicional, como se pode perceber, está marcada pela reciprocidade violenta.

Por esse motivo, o "midrash do tempo messiânico" implica na depuração desse traço totalitário do cristianismo para abrir passagem a uma nova "apologética da vulnerabilidade como espaço intersubjetivo de realizaçáo do desígnio divino" ${ }^{23}$. Nesse caso, a redençẫo assume o rosto da superação do ódio e do ressentimento e da inauguração da identidade relacional, abrindo espaço para a reconciliação através do perdão. Enfim, a escatologia em tempos pós-modernos há de revelar o rosto compassivo de Deus todo-amoroso como presença silenciosa do Deus absconditus, que se diz

é sua "impotência potente".

${ }^{20}$ Ídem, "Escatología y apocalipsis en tiempos posmodernos", 388.

${ }^{21}$ Ídem, El Dios escondido de la posmodernidad. Deseo, memoria e imaginación escatológica. Ensayo de teología fundamental pós-moderna, 274.

22 Ídem, Deus ineffabilis. Una teología posmoderna de la revelación del fin de los tempos, 39.

${ }^{23}$ Ídem, El Dios escondido de la posmodernidad. Deseo, memoria e imaginación escatológica. Ensayo de teología fundamental pós-moderna, 229-230. 
na carnalidade da "vítima perdoadora" ${ }^{24}$ e dos justos da história e, de maneira plena e definitiva, na vida de Jesus de Nazaré.

\section{Tempo messiânico como temporalidade kairológica: a novidade paulina}

Outro passo importante na tessitura do "midrash da temporalidade messiânica" se dá com a mediação da exegese e da hermenêutica pós-moderna, sobretudo com a The Third Questions, para reabilitar a escatologia paulina como temporalidade kairológica numa perspectiva existencialista. O anúncio do "fim dos tempos" como uma nova existência, isto é, enquanto escatologia realizada é, com efeito, a novidade da interpretação paulina.

Para o teólogo mexicano, recuperar a experiência do "fim dos tempos" descrito por Paulo será um "acto de recuperación de la existencia precária del creyente que vive "la paciencia de Dios" (Rom 3.26) en medio de las historia de devastación planetaria" 25. Com efeito, esta existência designa uma experiência da "nova temporalidade" como realização de uma vida em doação enquanto princípio da nova criação inaugurada por Jesus Cristo.

Seguindo, pois, o exegeta Helmut Koester, Carlos Mendoza supera a interpretação moderna da realidade do "fim dos tempos" na perspectiva cronológica da teologia paulina e protopaulina, pois coloca em relevo que Paulo anunciou o "fim dos tempos" em chave kairológica, de modo que a ideia cronológica é suplantada pela compreensão do anúncio sob a temporalidade escatológica como kairós ${ }^{26}$. Ora, essa hermenêutica da ideia do "fim dos tempos" em chave kairológica possibilita, pois, a assunção do horizonte existencial da interpretação da espera do Dia do Senhor no seio da comunidade transformada em sua esperança pela ação eminente de Deus.

\section{Hermenêutica pós-moderna do tempo messiânico e kairológico}

Partindo da volta às fontes bíblicas com a reabilitação da ideia do "fim dos tempos" em chave kairológica, o teólogo mexicano interpreta o tempo messiânico como uma

\footnotetext{
${ }^{24}$ Caldeira, "Tempo messiânico e sacramentalidade da subjetividade vulnerável na obra de Carlos Mendoza Álvarez". O conceito da "vítima perdoadora" (the forgiving victim), designa a original intuição do teólogo britânico James Alison em sua "recepção criativa" da teoria mimética de René Girard. Em Carlos Mendoza a aparição do Crucificado-que-vive, revela a "(im)potência potente" como núcleo da subjetividade e, assim, inaugura uma nova ontologia relacional marcada pela gratuidade.

${ }^{25}$ Mendoza Álvarez, Deus ineffabilis. Una teología posmoderna de la revelación del fin de los tempos, 102.

${ }^{26}$ Ibid., 123.
} 
"intensificação da temporalidade" ${ }^{27}$. Essa compreensão da temporalidade messiânica se tornou possível pela 'contração do tempo' instaurada pelo Messias, segundo a leitura paulina. O esforço de "voltar às fontes", entretanto, não se restringe a um movimento do labor teológico, constitui-se também numa proposta vinculada ao niilismo pós-moderno ${ }^{28}$.

E, sob o marco niilista, Carlos Mendoza enfatizará que a recepção pós-moderna do pensamento paulino se dá no contexto do colapso do Ocidente de suas instituiçóes fundacionais: a economia de mercado globalizado e a política do Estado secular. Voltar a falar do tempo messiânico, sobretudo depois do fracasso dos messianismos políticos do século XX -seja em sua versão religiosa ou secular-, se constitui em um propósito "muy atrevido" 29 . Entretanto, está na ideia do "fim dos tempos" a possibilidade de abertura de uma esperança realista, capaz de desativar o fatalismo ou a inercia diante da espiral de violência de alcance planetário ${ }^{30}$.

Ora, essa violência que conhecemos desde Caim e Abel, não cessou na história humana. Antes, seguindo o realismo histórico de René Girard, o teólogo mexicano enfatiza o crescimento desmedido da violência como jamais visto em toda a história da humanidade ${ }^{31}$. Essa consciência emerge da constataçáo do eminente risco de destruição da humanidade e do planeta inteiro, de modo que isso o levará a pensar em uma outra saída para a humanidade em pôr fim à "espiral de violência" ${ }^{32}$. Longe de cair num pessimismo, o teólogo olha com esperança a realidade, pois, para ele, esta realidade apocalíptica está prenhe da possibilidade de uma nova temporalidade: marcada pelo seu caráter messiânico e kairológico.

Essa compreensão enraíza-se na sua interlocução com o nilismo heideggeriano acerca da ideia histórica do tempo kairológico, mais especificamente na analogia entre a "angústia ontológica" e a "esperança cristâ" ${ }^{3}$. Neste sentido, nosso autor reconhece que esta angústia "da paso a la esperanza como experiencia de gratuidad desde la

${ }^{27}$ Ibid., 454.

${ }^{28}$ Caldeira, "Teologia e niilismo pós-moderno. A subjetividade vulnerável como locus theologicus no pensamento de Carlos Mendoza Álvarez”, 819-823.

${ }^{29}$ Mendoza Álvarez, "Escatología y apocalipsis en tiempos posmodernos", 395.

${ }^{30}$ Ídem, Deus ineffabilis. Una teología posmoderna de la revelación del fin de los tempos, 165.

${ }^{31}$ Ibid., 455.

32 Ibid., 107. O conceito de "espiral de violência" [montée aux extremes] foi cunhado por René Girard para descrever a violência crescente que ameaça o futuro da humanidade, como fruto do desejo mimético desenfreado (Mendoza Álvarez, Deus ineffabilis. Una teología posmoderna de la revelación del fin de los tiempos, 107).

33 Ídem, "Heidegger y la teología posmoderna. Diálogo en torno a la situación histórica del tiempo kairológico", 337-365. 
precariedade" ${ }^{34}$. Semelhante à contração das dores de parto, essa angustia anuncia a chegada de uma nova vida, da qual está prenhe a humanidade.

Seguindo no delineamento da "existência autêntica", o frei dominicano propõe uma "hermenéutica del messianismo en cuanto transformación cualitativa de la historia" ${ }^{35}$. Segue, pois, a interpretação do tempo messiânico do filósofo italiano Giorgio Agamben, que compreende que o tempo do Messias não é um período cronológico, mas transformação qualitativa do tempo vivido ${ }^{36}$. Em consonância com Agamben, ele pensa a parusia como um acontecimento que transforma a temporalidade ${ }^{37}$ e postula uma hermenêutica como "salto qualitativo" realizado na história por meio dos gestos de extrema gratuidade dos justos e das vítimas que sabem perdoador. Com isso se pode afirmar que a inovação do teólogo mexicano radica na conjugação entre escatologia niilista e existência teologal dos justos e das vítimas da história violenta.

A transformação qualitativa da história operada pela temporalidade messiânica em tempos pós-modernos é realizada por meio dos gestos de extrema gratuidade dos justos da história e, de modo crucial, pelas vítimas perdoadoras. São eles e elas que "contraem o tempo" por meio de seus atos de extrema gratuidade, onde acontece a intensificação da temporalidade. Em sentido teológico, tais atos dos justos e das vítimas da história são "gestos messiânicos" que manifestam a passagem do mistério amoroso do real. São elas e eles que por meio dos gestos éticos obstinados redime a todos, vítimas e verdugos. Desse modo, o messianismo da "teologia niilista pós-moderna” não é outra coisa senão uma hermenêutica da existência teologal dos justos e das vítimas perdoadoras.

Hablamos aquí de un mesianismo situado en el corazón de la historia, no en el sentido de una utopía del Reinado de Dios que se realiza plenamente en la tierra a través de mediaciones sociales y políticas, o por la instauración de proyectos económicos específicos, sino que postulamos una hermenéutica del mesianismo en cuanto transformación cualitativa de la historia a partir de los actos de gratuidad de los justos y, de manera crucial, surgida del perdón ofrecido por las víctimas que logran derribar "el muro del odio". ${ }^{38}$

Para fazer esta correlação do tempo messiânico com a existência teologal dos justos e das vítimas, o frei dominicano retoma a antiga ideia hebraica das farpas do

\footnotetext{
${ }^{34}$ Ibid., 337-365.

${ }^{35}$ Ídem, Deus ineffabilis. Una teología posmoderna de la revelación del fin de los tempos, 454.

${ }^{36}$ Agamben, "Cristianismo como religião: a vocação messiânica".

${ }^{37}$ Mendoza Álvarez, Deus ineffabilis. Una teología posmoderna de la revelación del fin de los tempos, 167.

${ }^{38}$ Ibid., 454.
} 
tempo messiânico consagrada pelo filósofo Walter Benjamin. Ela se constitui na chave semântica para compreender a paradoxal experiência da violência humana em tempos pós-modernos.

Benjamin falou da ideia de farpas do tempo messiânico como uma plenitude da história sempre diferida. Na filosofia política, essa ideia descreveu aquela realidade que dói como um ferrão na memória da humanidade cada vez que um inocente é injustiçado ou um justo é aniquilado ${ }^{39}$. Com efeito, essa interpretação do messianismo paulino em pleno século XX colocou o Ocidente a pensar no sentido possível do sem-sentido da morte das vítimas sistêmicas.

Entretanto, superando essa interpretação secular do tempo messiânico, Carlos Mendoza reabilita o sentido teologal do messianismo através da leitura niilista das farpas do tempo messiânico levado ao seu paroxismo pelo sentido escatológico inovador do apóstolo Paulo ${ }^{40}$. Nessa perspectiva, se por um lado, a existência teologal dos justos e das vítimas perdoadoras é interpretada como aquele ferrão que dói cada vez que um justo é aniquilado, por outro lado, apresenta-se como aquela ferida que cura enquanto metáfora da entrega desmedida. Trata-se da dupla faceta da temporalidade messiânica cumprida através da existência teologal dos justos e das vítimas da história, do cumprimento escatológico da célebre expressão de Isaías 53.5, de que pelas feridas dos justos somos todos curados ${ }^{41}$.

\section{Evento originário: irrupção do messiânico como per-dón}

Chega-se, assim, ao coração do "midrash do tempo messiâncino", que permite acessar o manancial divino como fonte e origem de toda a subjetividade em doaçáo. $\mathrm{O}$ midrash é, pois, a própria atualidade do evento originário da redenção como experiência da revelação de Deus. Por meio dele [do midrash] descobre-se o fundo amoroso do real como sentido último das realidades criadas.

Esse sentido último é também conhecido como eschaton, onde acontece o cumprimento feliz da comunhão humano-divino, cuja plenitude se cumpriu na kénosis do Verbo divino ${ }^{42}$. A esse fundo amoroso do real, Jesus de Nazaré chamou de Abba e, assim o revelou como superabundância de amor e perpétua doação. Nessa realidade transcendente revelada na imanência do Crucificado-que-vive encontra-se a verdade e o sentido capaz de redimir a humanidade e toda a criação.

\footnotetext{
${ }^{39}$ Ibid., 168-177.

${ }^{40}$ Ibid., 173.

${ }^{41}$ Ibid., 459-460.

42 Ídem, “Teología de la reconciliación en clave mimético-pragmática”, 199-212.
} 
A fenomenologia da subjetividade exposta colocou em suspensão de juízo as mediaçóes da ordem da crença, nas quais a religião, o sacrifício e a ideia de Deus todo-poderoso foram colocadas em parêntesis ${ }^{43}$. Com isso, o midrash apoiado na fides que brota do despojamento da subjetividade pode alcançar o coração da páscoa de Jesus, isto é, a fonte trancendente do real. Nos monoteísmos este fundo sem fundo do real foi identificado com certa ideia de Deus totalidade.

No entanto, o cristianismo pós-metafísico o reabilitou em função do Deus trinitário exposto no amor. Isso porque ao apostar no desenvolvimento de uma ontologia da gratuidade, Carlos Mendoza redescobre a pericorese divina como a fonte da identidade relacional, a partir da centralidade da alteridade e da comunhão na diferença revelada no "princípio kenótico" do evento Cristo ${ }^{44}$. Superada, pois, a ordem da crença, tem-se acesso à subjetividade vulnerável unida à sua fonte originária sob o dinamismo da theosis, isto é, da vida teologal.

Ultrapassando a ideia abstrata da verdade da revelação, com o "midrash da temporalidade messiânica" justifica-se o acesso fenomenológico à experiência originária de Jesus de Nazaré. Nessa volta à experiência fundacional do Verbo encarnado compreende-se a dinâmica soteriológica da kénosis-theosis como percepção da transcendência na imanência em vista da redenção de toda a criação.

Esse movimento de reabilitação da experiência originaria da fé da subjetividade pós-moderna como núcleo do "midrash do tempo messiânico", descreve a fides cristã em torno do tradiconal axioma da fides qua e fides quae. Por fides qua entende-se a experiência da fé associada ao evento originário de ordem histórica e teologal focado em Cristo, que em sua aparição como vítima perdoadora se dá como per-don à comunidade de sobreviventes.

Em outras palavras, a fides qua nos remete ao processo de percepção da transcendência na imanência como um momento fenomenológico ${ }^{45}$, no qual Deus se revela como "potência impotente" na kénosis do Verbo e nos interpela a acolhê-lo nesse dom. Esse evento originário da fé kenótica na vítima perdoadora se dá sob uma nova gramática, na qual se torna possível conjugar o verbo crer/amar em tempos pós-modernos. Essa gramática se constitui na dimensão da fides quae como desdobramento da "gramática da gratuidade" possibilitada pela vítima perdoadora, a única capaz de "dizer a profundidade crista" 4 .

43 Caldeira, "Desconstrução do cristianismo: imperativo ontológico à experiência de Deus na pósmodernidade" [no prelo].

${ }^{44}$ Mendoza Álvarez, El Dios escondido de la posmodernidad. Deseo, memoria e imaginación escatológica. Ensayo de teología fundamental posmoderna, 327.

45 Ibid., 336.

${ }^{46}$ Ibid., 283. 


\section{Experiência originária de Jesus de Nazaré}

No "midrash do tempo messiânico" o acesso a experiência originária do tempo escatológico passa pela reabilitação do Jesus histórico, pois o sentido primeiro do anúncio do fim dos tempos encontra-se nos "ditos e feitos" de Jesus de Nazaré. Essa experiência originária do judeu pregador itinerante em meio aos excluídos da Galileia dos gentios do século I e.c., possibilita repensar a crise de ordem global, visto que a prática de amor universal jesuânica emerge como critério para a teologia a partir das vítimas ${ }^{47}$.

O midrash assume o dramatismo do real com toda a sua carga mimética, com uma intelecção teológica a partir do "olhar da vítima perdoadora" $48 \mathrm{em}$ "chave de doação" ${ }^{49}$, que permite compreender a magnitude do anúncio cristão do Crucificado-que-foi-despertado da morte como "vítima perdoadora"so. Torna-se central a compreensão do messianismo apocalíptico jesuânico na perspectiva da teoria do desejo mimético ${ }^{51}$, pois o seu olhar apocalíptico e sua entrega gratuita assentaram as bases para o aparecimento do círculo vitimário ${ }^{52}$.

Assim, em Jerusalém se instalou o mecanismo do bode expiatório que conduziu Jesus à morte, como acontece com toda execuçáo emissária ${ }^{53}$. No seio do círculo mimético, em uma atitude de "renúncia à violência" e convicto de uma doaçấo extrema de si mesmo, dando testemunho profético e messiânico ele se entregou sem reservas a seu Abba no Getsêmani e a consumou no Gólgota ${ }^{54}$.

${ }^{47}$ Ídem, “De los márgenes al centro vacío. Aportes de la posmodernidad a la teología de la liberación”, 89.

48 Ídem, El Dios escondido de la posmodernidad. Deseo, memoria e imaginación escatológica. Ensayo de teologia fundamental posmoderna, 328.

${ }^{49}$ Ídem, Deus ineffabilis. Una teología posmoderna de la revelación del fin de los tempos, 343.

${ }^{50}$ Alison, O pecado original à luz da ressurreição: a alegria de descbrir-se equivocado. A "vítima perdodaora" advém da escatologia de James Alison em sua criativa recepção a teoria do desejo mimético de René Girard, para descrever a aparição do Curicificado-ressuscitado em sua aparição à comunidade de discípulas e discípulos.

${ }^{51}$ Girard e Chantre, Rematar Clausewitz. Além da guerra. Diálogos com Benoit Chantre.

${ }^{52}$ Caldeira, "Tempo messiânico e sacramentalidade da subjetividade vulnerável na obra de Carlos Mendoza Álvarez”, 87-92. Carlos Mendoza segue de perto a teoria do desejo mimético de René Girard, que pode ser descrita em quatro estágios consecutivos da "relação intersubjetiva": (1) O duplo mimético, isto é, o desejo de um bem ostentável por outrem, o outro me serve como modelo. (2) O contágio mimético, isto é, a instauração da rivalidade e do conflito. Essa rivalidade instaura o conflito intersubjetivo que tende a contaminar toda a sociedade, visto que o desejo mimético é sempre coletivo. O "contágio mimético" designa a contaminação coletiva da rivalidade. (3) O bode expiatório, pois o sacrifício de um terceiro é a forma de apaziguar o conflito. E, para que esse mecanismo seja eficaz, é importante que todos os envolvidos no processo estejam convictos da culpabilidade de vítima. (4) a divinizaçáo do processo; A sacralização do processo não é outra coisa senão a sacralização da própria violência.

${ }^{53}$ Mendoza Álvarez, Deus ineffabilis. Una teología posmoderna de la revelación del fin de los tempos, 249.

54 Ídem, El Dios escondido de la posmodernidad. Deseo, memoria e imaginación escatológica. Ensayo de teología fundamental posmoderna, 272. 
Essa doação do Espírito por Jesus na cruz é compreendida como antecipação messiânica da temporalidade escatológica concretizada no kairós de sua vida entregue por amor. Assim, a existência agônica tal como a caracterizou Ricoeur, ao referir-se à vida doada até o fim, é associada à figura do Nazareno, cuja obra de redenção caracteriza-se pela derrocada do muro do ódio no próprio corpo entregue na cruz.

\section{Inauguração do tempo escatológico}

A ressurreição de Jesus inaugura uma nova ordem de existência, na qual a subjetividade é habilitada ao estágio do mútuo reconhecimento na gratuidade. A partir da experiência pascal, Cristo passa a simbolizar a alternativa de dizer o real humano-divino segundo a lógica da doação. Em sua doação extrema, ele "mostró la apertura constitutiva del subjeto a su propia finitude y vulnerabilidad, al mismo tiempo que inauguro la posibilidad de la criación nueva por medio del perdón"s5.

A inauguração do tempo escatológico será, pois, descrita em linguagem apocalíptica como fim do mundo e advento do Reinado escatológico de Deus. É, com efeito, o anúncio apocalíptico do "fim dos tempos" como redefinição dos traços da condição humana, cuja fonte primigênia é a Sabedoria divina, que póe em juízo a rivalidade mimética ${ }^{56}$. A irrupção do tempo escatológico traz à luz a condição humana ontológica reconciliada, como aquela a quem se concedeu o poder de abandonar o ódio e o ressentimento por meio do perdão do Crucificado.

Esses traços antropológicos da condiçáo humana reconciliada são, por sua vez, eventos que se atualizam através da 'contração do tempo' que se cumpriu em Jesus de Nazaré de maneira plena e definitiva ao oferecer-se como per-dón. Essa 'contraçáo do tempo' torna-se princípio de uma ontologia relacional na gratuidade ${ }^{57}$, por meio da qual o evento originário se atualiza na história da humanidade a partir da existência em doaçâo das vítimas e dos justos da história. É, pois, o nascimento da identidade relacional ligada à fonte inesgotável de gratuidade, que se funda no encontro com Jesus de Nazaré com o $A b b a^{58}$.

Com uma aproximação fenomenológica à ressurreição e à irrupção da fides como experiência do Ressuscitado implode-se a ideia objetivista da Ressurreição. A partir desse novo marco, é possível acessar e acolher o conteúdo kerigmático e os seus

\footnotetext{
${ }^{55}$ Ibid., 308.

${ }^{56}$ Ídem, "Escatología y apocalipsis en tiempos posmodernos", 397.

${ }^{57}$ Ídem, Deus ineffabilis. Una teología posmoderna de la revelación del fin de los tempos, 415.

58 Ídem, El Dios escondido de la posmodernidad. Deseo, memoria e imaginación escatológica. Ensayo de teologia fundamental posmoderna, 278.
} 
desdobramentos na (inter)subjetividade em tempos de fragmentos. $\mathrm{Na}$ experiência kerigmática da fides, a ressurreiçâo inaugura uma ontologia relacional da gratuidade. Nela, a confissão de fé no Ressuscitado dá-se como aceitação de que o eu não existo sem o outro, ou melhor, o corpo glorioso de Cristo não existe fora do estágio do mútuo reconhecimento na gratuidade: do "nós".

Com a experiência da ressurreição de Jesus também ocorre uma implosão em nossa ideia de Deus. Nela somos interpelados a abandonar aquela ideia de um Deus agregado à justiça retributiva, a partir da qual se exige justiça para as vítimas e vingança para os verdugos. Somos convidados a nos abrir à intelecção de uma soteriologia a partir das vítimas sem excluir os verdugos. Isso significa que a redenção passa pela renúncia do desejo mimético violento estruturado na rivalidade em vista da acolhida de uma práxis de doação na lógica da gratuidade.

Em funçâo dessa modalidade soteriológica, trata-se de insistir na implosão da temporalidade cronológica e sua inevitável sequela apocalíptica revelada pela páscoa de Jesus de Nazaré. É a inauguração na história do tempo escatológico ${ }^{59}$, a nova criação em Cristo. Essa temporalidade designa a desconstrução do corpo histórico preso à experiência do chronos e a revelaçáo do corpo escatológico sob a dinâmica do kairós. Se na experiência do chronos nos encontramos presos no solipsismo do ego, na dinâmica do kairós emerge a possibilidade real de instauração da intersubjetividade, isto é, do mútuo reconhecimento na gratuidade do Ressuscitado.

A ressurreição designa, portanto, o fim do tempo em que a subjetividade ensimesmada se vê metafisicamente presa pela recuperação do corpo da vítima Jesus. Esse evento inaugura um novo jeito de ser no mundo marcado, enfim, pelo reconhecimento escatológico daquele que antes era visto como rival e inimigo para a condição de filha e filho de Deus e irmã e irmão em Cristo.

Vida nueva en tanto experiencia alternativa al mundo narcisista de la ipseidad. Tiempos mesiánicos cumplidos en la vida de un Crucificado-que-vive (bo stauroménos egertè), siempre en la discreción del Dios que se retira (Shabbat) en su silencio para hacer nuevas todas las cosas por la unción eficaz de su Ruah divina, que hace surgir siempre su signo de alianza: como arco iris colgado en el cielo que renuncia a la violencia, una vez que el arca naufragó, para ratificar su deseo perene de dar vida a todos. Primicias de la vida en plenitud que nos aguarda. ${ }^{60}$

59 Ídem, Deus ineffabilis. Una teología posmoderna de la revelación del fin de los tempos, 175.

${ }^{60}$ Ídem, El Dios escondido de la posmodernidad. Deseo, memoria e imaginación escatológica. Ensayo de teología fundamental posmoderna, 280-281. 
Em suma, a ressurreição marca o renascimento da subjetividade para a gratuidade no Crucificado-ressuscitado por meio da qual poderemos acolher o "si mesmo como outro" na dinâmica da fides ${ }^{61}$. E com isso a reconciliação torna-se possível como o estágio fundante da intersubjetividade.

Entretanto, recorda-nos o teólogo mexicano, essa realidade intersubjetiva como reconciliação só nos é possível como "indício escatológico", já que ela aparece sempre diferida na história ${ }^{62}$. Mas a existência messiânica inspirada pelo amor assimétrico e gratuito do Messias Jesus e dos justos da história, associada à sua "imaginação escatológica”, faz com que a temporalidade cronológica abra espaço para a temporalidade messiânica, instante em que a salvação vem ao encontro da finitude humana, redimindo-a de sua contradiçâo fraticida e sororicida ${ }^{63}$.

\section{Dom da Ruah divina como inteligência da vítima}

O evento Cristo como experiência originária trouxe uma nova compreensão do real, porque tornou possível uma nova experiência de Deus, de ser humano e do mundo. A doação amorosa "sem condição nem medida" que realiza em Jesus Cristo, à imagem de seu Abba e pela força da Ruah divina que o habita permanentemente, emerge como "critério último de interpretação da existência humana autêntica" ${ }^{64}$.

Em consonância com o teólogo James Alison e a racionalidade pós-moderna ${ }^{65}$, Carlos Mendoza descreve o kerigma fundador do novo mundo como "anúncio do fim do mundo e advento da salvação" como o dom gratuito ${ }^{66}$. Esse kerigma designará o "fim dos tempos" como redefinição dos traços da condição humana, de uma condição estruturada na rivalidade mimética à condição estruturada na gratuidade e, por isso, reconciliada. Sob a dinâmica da "imaginação escatológica", o acesso ao kerigma da ressurreiçáo deu-se em meio à busca por um sentido ao sem-sentido da morte de Jesus, através da releitura midráshica das Escrituras hebraicas ${ }^{67}$.

\footnotetext{
${ }^{61}$ Ibid., 285.

${ }^{62}$ Idem, "Subjetividad posmoderna e identidad reconciliada. Una recepción teológica de la teoría mimética”, 149-158.

${ }^{63}$ Ídem, "Escatología y apocalipsis en tiempos posmodernos", 395.

${ }^{64}$ Ídem, Deus ineffabilis. Una teología posmoderna de la revelación del fin de los tempos, 457.

${ }^{65}$ Alison, El retorno de Abel. Las huellas de la imagincaión escatológica.

${ }^{66}$ Mendoza Álvarez, El Dios escondido de la posmodernidad. Deseo, memoria e imaginación escatológica. Ensayo de teología fundamental pós-moderna, 274.

${ }^{67}$ Ídem, Deus ineffabilis. Una teología posmoderna de la revelación del fin de los tempos, 249.
} 
Nesse processo mediado pela imaginação escatológica e graças à aparição do Crucificado-ressuscitado, a comunidade em crise recebeu o dom da "inteligência da vítima" (intelligence of the victima) ${ }^{68}$. A inauguração do tempo escatológico, pois, como irrupção da Ruah divina enquanto dom da "inteligência da vítima" habilitou a comunidade messiânica a compreender a dinâmica interna que inspirou a vida e a morte do Nazareno. Na vivência de "permanente descentramento do ego" se constituiu a subjetividade de Jesus e lhe possibilitou outra maneira de viver o desejo ${ }^{69}$. "Si Jesús de Nazaret fue capaz de enfrentar el mecanismo mimético es porque le habitaba una fuerza que, incluso en el momento de su agonía, le hizo capaz de entregarla a sua vez como encargo a la comunidad messiânica" ${ }^{70}$.

Enfim, com os relatos da apariçấo do Crucificado-que-vive e o acesso a esta chave hermenêutica, a comunidade messiânica pôde compreender que o sucedido com Jesus de Nazaré revela-se como "el fin del poder de Satán y la instauración del Reinado de Dios" "1. A partir disso, a superação do ódio e a inauguração de uma ontologia relacional sob a gramática da gratuidade, a partir da vítima perdoadora, se cumpre uma nova criação graças à vítima que ao ressuscitar ressuscita consigo a história e a humanidade do caos do desejo mimético violento.

\section{Recuperação do centro vazio a partir da vítima perdoadora}

$\mathrm{O}$ "midrash da temporalidade messiânica" pode ser retomado para justificar a "esperança (im)possível” para os crucificados e às vítimas inocentes em tempos de crescente exclusão e violência. Nele, a esperança para as vítimas passa impreterivelmente pela recuperação do fundo sem fundo do real.

"Ese centro vacio que es el amor de donación que une con su Abba y que celebramos como don de la Ruah divina. Aquella que libera a los cativos y da vida a la creaturas todas rescatándolas de la aniquilación”72.

${ }^{68}$ Ídem, El Dios escondido de la posmodernidad. Deseo, memoria e imaginación escatológica. Ensayo de teología fundamental pós-moderna, 273. A “inteligência da vítima” é um conceito cunhado por James Alison, em sua criatica recepção da teoria do desejo mimético de René Girard, para descrever a dinâmica interna que inspirou toda a vida de Jesus (consultar: Alison, El retorno de Abel. Las huellas de la imagincaión escatológica).

${ }^{69}$ Mendoza Álvarez, El Dios escondido de la posmodernidad. Deseo, memoria e imaginación escatológica. Ensayo de teología fundamental pós-moderna, 274-275.

${ }^{70}$ Ídem, "El papel de la existencia kairológica como crítica al sistema hegemónico y a la violencia global”, 34.

${ }^{71}$ Ídem, El Dios escondido de la posmodernidad. Deseo, memoria e imaginación escatológica. Ensayo de teología fundamental pós-moderna, 273.

${ }^{72}$ Ídem, “De los márgenes al centro vacío. Aportes de la posmodernidad a la teología de la liberación”, 91. 
Focado nesse "centro vazio" que conduz às margens da história de dominação, o "midrash do tempo messiânico"permite a reaproximação de uma escatologia esculpida sob o signo do retorno de Abel, cuja significação encontra-se na aparição da "vítima perdoadora". Inscrito, pois, na proto-história de Caim e Abel, o retorno de Abel aparece como o reverso da história caínesca. Essa figura escatológica passa a designar o aparecimento histórico do justo aniquilado pelo mimetismo violento como "vítima perdoadora" e, portanto, com a potência de instaurar outra temporalidade por meio do perdáo.

Cristo "representa 'el retorno de Abel', que perdona a su hermano Caín, su propio verdugo, abriendo un camino histórico a la concreción escatológica de la redención y dejando traslucir así su plena humano-divinidad"73. Longe de condenar a seus seguidores pela sua debilidade por abandoná-lo, Jesus expóe suas feridas como sinal de oferenda de sua própria vida ${ }^{74}$.

Assim, nessa experiência de exposição da "(im)potência potente" da "vítima perdoadora" se faz a experiência de Deus em seu despojo, isto é, a experiência da "potência impotente" na cruz que na ressurreição revela sua fraqueza no amor. E mais, nessa experiência em que a "vítima perdoadora" se entrega como dom, a subjetividade experimenta Deus em sua própria vulnerabilidade, livrando-a, assim, do ressentimento da fraqueza da subjetividade. Essa "(im)potência potente" torna-se a potência de experiência capaz de transfigurar o mundo violento da (inter)subjetividade.

Essa percepção de Deus por meio do per-dón, designa essa aproximação apofática ao Abba de Jesus, isto é, o "centro vazio" que não se pode apoderar jamais. Com isso, a redenção humana passa a depender de nossa relação com a "vítima perdoadora", pois ela se torna o sacramento da ação do Deus escondido e inefável no seio da história conflitiva e fragmentada da pós-modernidade.

Este despliegue de la fuerza de Dios en la debilidad del inocente es una verdadera buena noticia para todos, para las víctimas y para los verdugos encarnizados: para los débiles resentidos al convocarlos a la superación de la sed de venganza sin renunciar a la justicia, pero también para los guerreros vencedores que viven la ilusión narcisista que tarde o temprano se evapora. ${ }^{75}$

Ao fazer a experiência de Deus em seu despojo, a vítima experimenta outra ordem de existência, isto é, ela bebe na fonte de desejo vivido por Cristo. Não mais

\footnotetext{
${ }^{73}$ Ídem, Deus ineffabilis. Una teología posmoderna de la revelación del fin de los tempos, 322.

${ }^{74}$ Íbid., 320.

75 Ídem, El Dios escondido de la posmodernidad. Deseo, memoria e imaginación escatológica. Ensayo de teología fundamental pós-moderna, 334-335.
} 
nos poços das águas poluídas da reciprocidade violenta, nos quais residem o ódio e o desejo de vingança, que produz vítimas segundo o círculo vicioso do mimetismo sacrificial. Antes, a subjetividade reconciliada é inserida em um processo de santificação enquanto maneira de aprender a receber-se gratuitamente do outro e com os outros e para os outros como "per-dón".

\section{Existência kairológica: o evento originário da subjetividade messiânica}

Das feridas do Crucificado vivente surge a vida teologal [theosis] como repotencialização da subjetividade vulnerável, capacitando-a a viver o tempo escatológico inaugurado pelo Messias em meio ao dinamismo mimético violento. A vida teologal enquanto evento escatológico descreve a constituiçâo da subjetividade em sua significação messiânica, uma subjetividade encarnada na história sob o regime da "(im)potência potente", isto é, do mimetismo depurado da rivalidade.

A subjetividade vulnerável pós-moderna unida à temporalidade escatológica sob o dinamismo da theosis, insere na história a temporalidade messiânica através do perdão recebido e oferecido gratuitamente. Nesse dinamismo relacional, a subjetividade vulnerável alcança o seu estágio mais elevado, isto é, a sua significação messiânica, pois é vivida como temporalidade escatológica. Animada pelo dinamismo das virtudes teologais ela poderá viver o reverso da história de dominação sem ressentimento, sob a "(im)potencia potente" que revelou o Crucificado-ressuscitado.

Em outras palavras, a constituição da subjetividade como temporalidade messiânica é descrita a partir das virtudes teologais: a fé, a esperança e a caridade. Elas representam os estágios da constituiçâo da identidade relacional como uma existência kairológica, cuja concreção história se dá na vivência do amor desmedido e assimétrico dos justos e das vítimas perdoadoras da história. Como processos de subjetivação que realizam as vítimas da história, as virtudes teologais desconstruídas de seu desejo de possessão e habitadas pela força da temporalidade messiânica denunciam os ídolos que visam depor o mistério amoroso ${ }^{76}$.

\section{A fé no Deus da contra-história}

Da radical exposição da subjetividade à vítima perdoadora brota a fé como experiência e inteligibilidade capaz de transfigurar a vida humana e o mundo pós-moderno, a partir

${ }^{76}$ Ídem., "Pax Christi. Sobre el enigma de la violencia y la inteligencia cristiana para enfrentarlo”, 100-109. 
da assunção da "(im)potência potente" revelada na vítima Crucificada-ressuscitada ${ }^{77}$. $\mathrm{O}$ "midrash do tempo messiânico" refere-se à fé como convite a crer além dos muros da rivalidade mimética recepcionada como "inteligência da vítima"78. Um doloroso processo de constituição da subjetividade em sua significação messiânica, isto é, uma subjetividade que se sabe habitada pela alteridade amorosa, capaz de habitar a sua exclusão com esperança.

Nesse novo contexto, portanto, a fé refere-se à experiência e ao conhecimento do real à luz da vida de Cristo na vida das vítimas, enquanto irrupção da "verdade como acontecimento discreto" 79 no coração do mundo violento. Enquanto verdade, a fé implica em três elementos estruturantes da subjetividade: No primeiro elemento, a fé aparece como desvelamento da mentira de Satá, isto é, revela a estrutura mimética da subjetividade enquanto "pecado original" ${ }^{80} \mathrm{e}$ a exime do círculo vicioso, sinalizando outro modelo de desejo a imitar destituído da rivalidade. O segundo elemento da fé diz respeito ao movimento por excelência da verdade da vítima não ressentida, a única capaz de inaugurar um novo estágio intersubjetivo marcado pelo "reconhecimento escatológico" do rival e inimigo como irmão e irma ${ }^{81}$. O terceiro elemento estruturante da experiência de fé consiste na discrição do anúncio profético e messiânico da potência criativa do perdão enquanto desejo instaurado na relação-na-diferença, expressando, assim, a Imitatio Christi no coração do mundo pós-moderno ${ }^{82}$.

Sob a "gramática escatológica" ${ }^{3}$, portanto, a fé como "acontecimento discreto" se converte em uma verdade que anuncia o fim do mundo e o advento do Reinado de Deus no seio da história conflitiva. Não uma fé como alienação ou fuga do mundo, mas inserção na história sob a promessa de outro mundo possível vindo de Deus ${ }^{84}$.

Por isso a fé assume o mundo violento e contingente para espalhar em seu coração sementes de redenção $0^{85}$, sem com isso pretender negar os impasses próprios do desejo mimético violento e seu poder destrutivo ${ }^{86}$. Pelo contrário, a fé como práxis

77 Ídem., El Dios escondido de la posmodernidad. Deseo, memoria e imaginación escatológica. Ensayo de teologia fundamental pós-moderna, 281.

${ }^{78}$ Ibid., 279.

${ }^{79}$ Ibid., 313.

${ }^{80}$ Ibid., 314.

${ }^{81}$ Ibid., 285.

82 Ibid., 312.

${ }^{83}$ Ibid., 318. O conceito teológico de "gramática" é uma derivação das análises de Jean-Mac Ferry sobre as "potências de experiências" da subjetividade que designa a "existência autêntica".

${ }^{84}$ Ibid., 319.

${ }^{85}$ Ídem., Deus ineffabilis. Una teología posmoderna de la revelación del fin de los tempos.

${ }^{86}$ Ídem, El Dios escondido de la posmodernidad. Deseo, memoria e imaginación escatológica. Ensayo de 
alternativa ao mundo violento anuncia "justo ahí el fin del mundo atrapado en su propia vanidad y el advenimiento del Reinado de Dios" ${ }^{77}$.

Em suma, a virtude teologal da fides em chave pós-moderna traduz-se na potência da experiência da subjetividade exposta à alteridade e à transcendência, de modo a ser interpelada a transfigurar o mundo violento com a força inusitada do esquecimento e do perdão ${ }^{88}$. Com efeito, a estrutura da fé não se distingue de um doloroso processo que visa abandonar a lógica da totalidade, do ódio e do ressentimento ${ }^{89}$. Trata-se, pois, de associar a fé a uma "prática gramatical de acolhida da diversidade" fora da totalidade violenta, fundada na "diversidade transcendente" 90

Nesse sentido, a diversidade sobre a experiência de fé no Deus da contra-história não se fixa apenas num assunto ideológico de promoção da diversidade humana e tampouco numa prática política de promoção e defesa das minorias. Mas, sobretudo, essa fé no Deus da contra-história assume a diferença como desvelamento do rosto, do clamor e do chamado que vem da alteridade amorosa ${ }^{91}$.

\section{Esperança messiânica que contrai o tempo}

A virtude teologal da esperança encontra-se no centro da problemática pós-moderna, pois a crise da pós-modernidade tem seu núcleo na desesperança suscitada pelo colapso dos metarrelatos do Ocidente e da cristandade. Dissemos acima que a esperança em tempos pós-modernos só pode ser pensada sob a lógica da kénosis, quer seja do divino quer seja do humano.

Desta maneira, busca-se falar de uma "(im)possível esperança” que emerge do despojamento humano-divino, referendada pela encarnação do Filho. A recepçáo da obra da Ruah divina no coração do criatural-humano é, portanto, percebida como "trabalho de resistência e resiliência" a partir da vulnerabilidade de corpos e das subjetividades abertas à alteridade amorosa que habita o $\operatorname{cosmos}^{22}$.

teología fundamental pós-moderna, 291.

${ }^{87}$ Ibid., 322.

${ }^{88}$ Ibid, 336.

${ }^{89}$ Ibid., 285.

${ }^{90}$ Ibid., 322.

${ }^{91}$ Ibid., 322.

92 Ídem., "El papel de la existencia kairológica como crítica al sistema hegemónico y a la violencia global”, 37. 
Nessa perspectiva, a virtude teologal da esperança no coração dos tempos pós-moderno é experiência do "triunfo escatológico da cruz" ${ }^{33}$ e, concomitantemente, da "contraçẫo do tempo" messiânico realizada pelos justos da história. Será nesse horizonte escatológico inaugurado por Jesus e vivido pelos justos, isto é, na perspectiva kenótica que a subjetividade desconstruída poderá ser locus do cultivo da esperança da consumação da história. Esse cultivo da esperança se faz através da memória dos justos que foram aniquilados pela rivalidade mimética e resgatados por Deus em sua superabundância amorosa, tal como aconteceu com Jesus de Nazarép.

A esperança cristã em tempos pós-modernos, portanto, anuncia a ressurreição dos justos da história. Não pensemos que essa esperança se configura como escapismos diante da "crescente espiral de violência" e, portanto, espera de uma redençâo além da história. Essa perspectiva de esperança na bem-aventurança eterna está em suspensão de juízo, pois o "midrash do tempo messiânico" fala de uma “(im)possível esperança”.

La esperanza es, por tanto, un acto de digna rabia que exige memoria para promover justicia, pero que da paso al olvido y, quizás algún día, se atreve a oferecer el gesto de la reconciliación. [...]. La esperanza mesiánica es un proceso de subjetivación desde la resiliencia en medio del horror. Ella surge como gesto de compartir más allá de la codicia: pan partido, compartido y repartido en la mesa común de la existencia para todas y todos, cada quien desde su subjetivación conquistada como emancipación y autonomía desde la vulnerabilidad asumida, pero recibida como don por una alteridad amorosa que nos deletrea a todos. ${ }^{95}$

Pensar a questáo da esperança no midrash é um exercício em aprender a "esperar sem esperar nada", no sentido do un état d'âme, isto é, existindo somente como sendo dado pelos outros ${ }^{96}$. Aprender a esperar na gratuidade amorosa do outro exige da subjetividade uma renuncia ao desejo de possuir o porvir associado ao mero instinto de sobrevivência. A “(im)possível esperança” está circunscrita na intra-história de dominaçáo e de violência desmedida por meio dos gestos obstinados dos sobreviventes que não cessam de fecundar a terra esperando "contra toda esperança"

\footnotetext{
${ }^{3}$ Ídem, El Dios escondido de la posmodernidad. Deseo, memoria e imaginación escatológica. Ensayo de teología fundamental pós-moderna, 279.

${ }^{94}$ Ídem, Deus ineffabilis. Una teología posmoderna de la revelación del fin de los tempos, 429.

${ }_{95}$ Ídem, "El papel de la existencia kairológica como crítica al sistema hegemónico y a la violencia global", 39 (grifo autor).

${ }^{96}$ Ídem., Deus ineffabilis. Una teología posmoderna de la revelación del fin de los tempos, 428.

${ }^{97}$ Ibid., 463.
} 


\section{Caridade como o elo que une os cabos soltos da exclusão}

Como terceiro dinamismo que constitui a subjetividade em sua significação messiânica, a caridade desconstruída de seu "protagonismo autocomplacente" irrompe como experiência dos justos em função do "salto qualitativo" da história, que passa da violência mimética e do ressentimento à doação e a gratuidade no amor. Essa passagem se faz como experiência da compaixão extrema do Deus escondido e, também, oferecida pela vítima sem ressentimento ${ }^{98}$. Trata-se da existência kairológica capaz de viver a ordem teologal do ágape no Messias como incessante processo de doação às vítimas da história. Nesse processo a caridade instaura o reconhecimento como koinonia de Deus no coração da finitude da criação".

Se uma "(im)possível esperança" é passível de ser vivenciada em tempos de fragmentos, isso se justifica pelo fato de ser retroalimentada por uma "(im)possível doação". Se muitos analistas da subjetividade não creem na possibilidade histórica dessa difícil doação, por outro lado, o "midrash do tempo messiânico" insiste na "(im) possível doação" graças ao amor desmedido e assimétrico da subjetividade esvaziada do desejo mimético violento no contato com os excluídos da história. Com efeito, essa dimensão simbólica da subjetividade em sua significação messiânica constitui a novidade do cristianismo nesta hora de "crescente espiral de violência"100.

Seguindo a mística do despreendimento do Mestre Eckhart, o "midrash do tempo messiânico" testifica que a subjetividade vulnerável pós-moderna é capaz de voltar-se para o fundo sem fundo do real, fonte e horizonte de toda a subjetividade em doação. É, portanto, esse fundo sem fundo vivido no amor e no gesto messiânico de doação que ata os cabos soltos da história de exclusão, visto que ele se revela à subjetividade vulnerável em sua “(im)potência potente" como o nó da vida trinitária.

Em outras palavras, o dinamismo das virtudes teologais permite à subjetividade messiânica viver a temporalidade escatológica graças a interlocução do Deus ineffabilis que não cessa de redimir sua criação através dos gestos de gratuidade dos justos da história. Nisto se verifica a atualidade do "midrash do tempo messiânico" como gesto messiânico em seu movimento kenótico.

\footnotetext{
98 Ídem, El Dios escondido de la posmodernidad. Deseo, memoria e imaginación escatológica. Ensayo de teología fundamental pós-moderna, 280.

${ }^{99}$ Ibid., 313.

100 Íbid., 313.
} 


\section{Consideração final}

Descrever os traços constitutivo do cristianismo passível de ser vivenciado pela subjetividade pós-moderna, a partir da inovadora teologia de Carlos Mendoza Álvarez, trouxe à luz a força profética do cristianismo em sua capacidade de pôr fim à violência intersubjetiva em sua dimensão planetária. Constatamos que, com isso, Carlos Mendoza realizou uma hermenêutica kenótica que possibilitou pensar a esperança messiânica em termos de “(im)possível esperança”, visto que ela só é possível a partir da concepção kenótica de ser humano e de Deus. Foi nessa perspectiva kenótica que o teólogo mexicano teceu a sua teologia niilista da temporalidade messiânica, para dizer a fraqueza do mistério de Deus que se revela na temporalidade messiânica, mais especificamente na carnalidade dos justos da história e das vítimas perdoadoras.

Essa teologia niilista apareceu, pois, como um autêntico midrash da temporalidade messiânica no coração da pós-modernidade, como reabilitação da essência do cristianismo, visto que revelou a atualidade do evento Jesus Cristo. Esse midrash do tempo messiânico nos colocou em rota de conversão na direção do manancial divino, visto que ele é a própria atualidade do evento originário da redenção. Também, o midrash do tempo messiânico nos revelou que a origem e o destino de toda subjetividade em doação é a gratuidade amorosa e não a rivalidade mimética.

Com o midrash do tempo messiânico, portanto, acessamos o sentido do fim da história anunciado pelo messianismo cristão. Não como um fim cronológico da teologia apologética com o consequente castigo para os verdugos e justiça para as vítimas, mas um fim kairológico como boa nova para vítimas e verdugos. Esse evento originário da fé como experiência com a "vítima perdoadora” exposta à subjetividade pós-moderna como núcleo do midrash da temporalidade messiânica, possibilita a recuperação do axioma da tradição cristá fides qua e fides quae.

Da exposiçáo da subjetividade pós-moderna às feridas do Crucificado-ressuscitado brota a vida teologal como repotencialização da subjetividade, capacitando-a com a "inteligência da vítima” perdoadora a viver o tempo escatológico inaugurado pelo Messias Jesus. A vida teologal desdobra-se no conjunto das virtudes teologais que se tornaram potências de experiência capazes de constituir a subjetividade em sua significação messiânica. A subjetividade messiânica revelou-se, pois, aquela que faz do perdão a sua habitação como temporalidade messiânica e, tendo atravessado a terra árida do ressentimento, transforma qualitativamente a história com o gesto messiânico inspirado em Jesus como doação.

Enfim, com o midrash do tempo messiânico pudemos apresentar à comunidade acadêmica porção considerável do pensamento teológico de Carlos Mendoza Álvarez, que coloca de maneira inovadora a racionalidade teológica em diálogo com a 
racionalidade pós-moderna. Longe de refutar a crítica niilista à vontade de poder que esteve atrelado à cristandade, o teólogo mexicano assume essa crítica como parte da evolução da razão e localiza nela a própria realização do princípio kenótico da fé cristã.

Com isso, o teólogo mexicano além de reabilitar a essência da fé cristã, anuncia a urgente tarefa da racionalidade teológica de renunciar a vontade de poder que está implícita na obstinada busca de sentido e retorno ao fundamento metafísico do real. Para o teólogo mexicano, já não é possível voltar à teocracia da cristandade, mas deve-se apostar na recuperação da essência da fé cristã enquanto acentecimento discreto, de um messianismo que fecunda a história com uma subjetividade vivida até o limite.

\section{Referências}

Agamben, Giogio. "Cristianismo como religião: a vocação messiânica" (2017). Instituto Humanitas Unisinos, http://www.ihu.unisinos.br/174-noticias-2010/567993cristianismo-como-religiao-a-vocacao-messianica-artigo-de-giorgio-agamben (consultado em 26 de agosto 2016).

Alison, James. El retorno de Abel. Las huellas de la imagincaión escatológica. Madrid: Herder, 1999.

- O pecado original à luz da ressurreição. A alegria de descbrir-se equivocado. São Paulo: É Realizações, 2011.

Caldeira, Cleusa. "Da Europa à América Latina. A vulnerabilidade como locus theologicus". Perspectiva teológica Vol. 50, N. ${ }^{\circ} 2$ (2018): 307-323.

. "Desconstrução do cristianismo. Imperativo ontológico à experiência de Deus na pós-modernidade". No prelo.

- "Fundamentos teológicos da política. Por uma reabilitação da fonte política da subjetividade em tempos pós-modernos". No prelo.

- "Tempo messiânico e sacramentalidade da subjetividade vulnerável na obra de Carlos Mendoza Álvarez”. Tese de Doutorado em Teologia, pela Faculdade de Filosofia e Teologia, FAJE, Belo Horizonte, 2017.

. "Teologia e niilismo pós-moderno: a subjetividade vulnerável como locus theologicus no pensamento de Carlos Mendoza Álvarez”. Revista Pistis \& Práxis 9, N. 3 (2017): 810-838.

De Santoyo, Juan Ruiz Gopegui. Experiência de Deus e catequese narrativa. São Paulo: Loyola, 2010.

Girard, René. Eu via satanás cair do céu como um raio. Lisboa: Intituto Piajet, 1999. 
. Mentira romântica e verdade romanesca. Trad. Lília Ledon da Silva. São Paulo: É Realizações, 2009.

Girard, René e Chantre Benoit. Rematar Clausewitz. Além da guerra. Diálogos com Benoit Chantre. São Paulo: É Realizações, 2011.

Knauer, Peter. "Ontologia relacional". Em Dios clemente y misericordioso. Enfoques antropológicos. Homenaje a Barbara Andrade, coordenado por Javier Quezada del Rio, 19-41. México: Universidad Iberoamericana, 2012

Mendoza Álvarez, Carlos. "A recepção inacabada do Concílio Vaticano II no mundo latino-americano e caribenho. O caso da teologia da revelaçáo". Em O Concílio Vaticano II Batalha perdida ou esperança renovada? Organizado por Agenor Brighenti e Francisco Merlos Arroyo, 265-287. São Paulo: Paulinas, 2014.

. "De los márgenes al centro vacío. Aportes de la posmodernidad a la teología de la liberación”. Liberation Theology and New Paradigms. EATWOT’s International Theological Commission. Vol. XXXVII N.o 2014/4 New Series (2014): 81-92. . Deus ineffabilis. Una teología posmoderna de la revelación del fin de los tempos. Barcelona: Herder-Universidad Iberoamericana, 2015.

. El Dios escondido de la posmodernidad. Deseo, memoria e imaginación escatológica. Ensayo de teología fundamental posmoderna. Guadalajara: SUJ, 2010.

- "El papel de la existencia kairológica como crítica al sistema hegemónico y a la violencia global". Em Tempos do Espirito: inspiracao e discernimento, coordenado por José Manoel Godoy, 31-42. Belo Horizonte/Sao Paulo: SOTER/ Paulinas, 2016.

. "Escatología y apocalipsis en tiempos posmodernos". Concilium 356 (2014): 387-398.

. "Heidegger y la teología posmoderna. Diálogo en torno a la situación histórica del tiempo kairológico". Pistis \& Praxis 8, N. 2 (2016): 337-365.

. "Pax Christi. Sobre el enigma de la violencia y la inteligencia cristiana para enfrentarlo”. Conspiratio Año II, N. ${ }^{\circ} 12$ (2011): 100-109.

. "Subjetividad posmoderna e identidad reconciliada. Una recepción teológica de la teoría mimética”. Universitas Philosophica Año 27, N. 55 (2010): 149-158. - "Teología de la reconciliación en clave mimético-pragmática". Em La participación de los cristianos en la construcción del espacio público, coordenado por Carlos Mendoza Álvarez, 199-212. México: Universidad Iberoamericana, 2011. 
Nancy, Jean-Luc. A adoração (Desconstrução do cristianismo, 2). Coimbra: Palimage, 2014.

. La declosión (Deconstrucción del cristianismo, 1). Buenos Aires: Ediciones La Cebra, 2008.

Robert, Jean y Majid Rahnema. La potencia de los pobres. San Cristóbal de Las Casas: Cideci, 2012. 